\title{
ANALISIS FAKTOR-FAKTOR YANG MEMPENGARUHI \\ PENGUNGKAPANCORPORATE SOCIAL RESPONSIBILITY \\ DI INDONESIA (STUDI EMPIRIS PADA PERUSAHAAN BERKATEGORI \\ HIGH PROFILE YANG LISTING DI BURSA EFEK INDONESIA)
}

\author{
Marzully Nur \\ Denies Priantinah M.Si.,Akt \\ Marzuly 024@yahoo.co.id \\ denies_priantinah@yahoo.com \\ Fakultas Ekonomi \\ Universitas Negeri Yogyakarta
}

Abstrak

\begin{abstract}
Penelitian ini bertujuan untuk mengetahui pengaruh profitabilitas,ukuran perusahaan, kepemilikan saham publik, dewan komisaris, leverage dan pengungkapan media terhadap pengungkapan Corporate Social Responsibility. Pemilihan variabel yang digunakakan dalam penelitian ini karena berbagai hasil penelitian menunjukkan hasil yang inkonsisten, selain itu pemilihan variabel pengungkapan media karena variabel ini masih jarang digunakan dalam penelitian di Indonesia yang mengkaji faktor-faktor pengungkapan CSR.

Populasi dalam penelitian ini adalah perusahaan berkategori high profile yang terdaftar di BEI periode 2008-2010 dengan 177 perusahaan. Metode pengambilan sampel menggunakan purposive sampling sehingga diperoleh 66 sampel penelitian.Metode analisis yang digunakan di da-
\end{abstract}

lam penelitian ini adalah metode regresi berganda. Hasil penelitian menunjukkan bahwa profitabilitas, kepemilikan saham publik dan pengungkapan media tidak berpengaruh terhadap pengungkapan CSR. Ukuran perusahaan berpengaruh positif dan signifikan terhadap pengungkapan CSR. Dewan komisaris dan leverage berpengaruh negatif dan signifikan terhadap pengungkapan CSR. Adapun profitabiltas, ukuran perusahaan, kepemilikan saham publik, dewan komisaris, leverage dan pengungkapan media (media exposure)secara bersama-sama (simultan) berpengaruh terhadap pengungkapan CSR.

Keywords :Corporate Social Responsibility, faktor -faktor yang mempengaruhi pengungkapan CSR. 


\section{A. Pendahuluan}

\section{Latar Belakang Masalah}

Kegiatan bisnis terutama yang bergerak di bidang pemanfaatan sumber daya alam baik secara langsung maupun yang tidak langsung tentu memberikan dampak pada lingkungan sekitarnya seperti masalah-masalah polusi, limbah, keamanan produk dan tenaga kerja. Adanya dampak pada lingkungan tersebut mempengaruhi kesadaran masyarakat akan pentingnya melaksanakan tanggung jawab sosial atau yang dikenal dengan CSR (Corporate Social Responsibility). Saat ini seluruh perusahaan berbagai sektor bisnis di Indonesia sebagian besar mengklaim bahwa perusahaan mereka telah melaksanakan kewajiban sosialnya terhadap lingkungan sekitar perusahaan, oleh karena itu, sebagian besar perusahaan tersebut melakukan pengungkapan Corporate Sosial Responsibility sebagai motivasi untuk meningkatkan kepercayaaan publik terhadap pencapaian usaha perbaikan terhadap lingkungan sekitar perusahaan. Seluruh perusahaan di Indonesia semakin dituntut untuk memberikan informasi yang transparan atas aktivitas sosialnya, sehingga pengungkapan terhadap Corporate Social Responsibility (CSR) diperlukan peran dari akuntansi pertanggungjawaban sosial (Fr. Reni, 2006).

Permasalahan-permasalahan sosial yang dihadapi oleh perusahaan di Indonesia juga terjadi karena lemahnya penegakan peraturan tentang tanggung jawab sosial perusahaan, misalnya tentang aturan ketenagakerjaan, pencemaran lingkungan, perimbangan bagi hasil suatu industri dalam era otonomi daerah (Eka, 2011). Selain itu, dalam Pernyataan Standar Akuntansi Keuangan (PSAK) No.1 (revisi 2009) paragraf 12 perusahaan masih bersifat sukarela dalam mengungkapkan CSR kepada publik melalui laporan tahunan perusahaan. Dampak dari belum diwajibkan PSAK untuk mengungkapkan informasi sosial menimbulkan praktik pengungkapkan informasi yang dilakukan oleh perusahaan umumnya bersifat voluntary (sukarela), unaudited (belum diaudit), dan unregulated (tidak dipengaruhi oleh peraturan tertentu) Eka (2011). Pemerintah juga mengeluarkan peraturan yang mengenai tanggung jawab sosial, yang diatur dalam Undang-Undang R.I. No. 40 tahun 2007 pasal 74 tentang tanggung jawab sosial dan lingkungan. Peraturan di atas menunjukkan bentuk kepedulian pemerintah terhadap masalah-masalah sosial, yang dalam hal ini adalah pertanggung jawaban sosial perusahaan.Namun belum ada standar mengenai seberapa banyak tanggung jawab sosial yang harus diungkap.

Berbagai penelitian terkait dengan pengungkapan CSR menunjukkan hasil yang beragam.Beberapa penelitian yang telah dilakukan menunjukkan adanya hubungan yang positif antara pengungkapan CSR perusahaan dengan profitabilitas (Theodoran dan Agus 2010, Sri dan Sawitri 2011 dan Achmad 2007). Akan tetapi beberapa penelitian lainnya menunjukkan adanya hubungan yang tidak signifikan antara profitabilitas dengan pengungkapan CSR (Fr.Reni 2006 dan Lidya,2011).

Berbagai penelitian yang berhasil membuktikan hubungan positif antara variabel ukuran perusahaan dan pengungkapan CSR antara lain dilakukan oleh Eddy (2005) serta Rahma dan Indah (2010). Tetapi tidak semua penelitian mendukung hubungan antara ukuran perusahaan dengan pengungkapan CSR perusahaan. Ada penelitian yang tidak berhasil menunjukan hubungan positif antar kedua variabel tersebut, yaitu penelitian yang dilakukan oleh Achmad (2007), Arief dan Kurnia (2008).

Dalam hubungan kepemilikan saham publik dan pengungkapan CSR juga menunjukkan hasil yang tidak konsisten.Hasil penelitian yang dilakukan oleh Puspitasasri dalam Eka (2011) menunjukkan bahwa kepemilikan saham publik berpengaruh terhadap pengungkapan CSR. Bertolak belakang dengan hal tersebut hasil penelitian yang dilakukan oleh Achmad Bajuri (2007), Eka (2007) serta Rivi dan Hasan (2011) menunjukkan bahwa kepemilikan saham publik tidak berpengaruh terhadap pengungkapan CSR.

Hubungan antara dewan komisaris dan pengungkapan CSR juga menunjukkan hasil yang tidak konsisten.Penelitian yang dilakukan oleh Luqman (2010) dan Chandra (2011) menyatakan bahwa dewan komisaris berpengaruh negatif terhadap pengungkapan CSR. Akan tetapi berbeda dengan hasil penelitian yang dilakukan oleh Theodora dan Agus (2010) dan Eddy (2005) yang menyatakan bahwa dewan komisaris berpengaruh positif dan signifikan terhadap pengungkapan CSR.

Leverage juga variabel yang banyak diindikasikan memiliki pengaruh terhadap pengungkapan CSR. Akan tetapi hasil penelitian juga menunjukkan hasil yang beragam. Hasil penelitian dilakukan oleh Lidya (2011) dan Aulia (2011) menunjukkan bahwa leverage berpengaruh negatif terhadap pengungkapan CSR tetapi berbeda dengan hasil penelitian Fr. Reni (2006) dan Eddy (2005) yang menemukan bahwa leverage tidak berpengaruh 
negatif terhadap pengungkapan CSR.

Pengungkapan media merupakan variabel yang masih jarang digunakan untuk menjelaskan pengaruhnya terhadap pengungkapan CSR. Hasil penelitian yang dilakukan oleh Aulia (2011) dan Reverte (2008) menunjukkan bahwa pengungkapan media tidak berpengaruh terhadap pengungkapan CSR, akan tetapi hasil penelitian (Bansal and Clelland, 2004;Bansal and Roth, 2000; Bowen, 2000; Henriques and Sadorsky, 1996) dalam Reverte (2008) menunjukkan bahwa pengungkapan media berpengaruh positif terhadap pengungkapan CSR.

Tujuan dilakukannya penelitian ini adalah untuk mengetahui pengaruh variabel profitabilitas, ukuran perusahaan, kepemilikan saham publik, dewan komisaris, leveragedan pengungkapan media terhadap pengungkapan CSR baik secara parsial maupun secara simultan.

\section{Kajian Literatur}

\section{1) Definisi dan Konsep Corporate Social Re- sponsibility}

CSR menurut Lord Holme dan Richard Watt, dalam Nor Hadi. 2011:46:"CSR adalah komitmen berkelanjutan dari perusahaan yang berjalan secara etis dan memiliki kontribusi terhadap pembangunan untuk meningkatkan kualitas hidup tenaga kerja dan keluarga mereka, dan juga komunitas lokal serta masyarakat luas".Pengertian CSR menurut Johnson dan Johnson, dalam Nor Hadi. 2011:46 menyatakan bahwa : "CSR is about how companies manage the business processes to produce an overall positive impact to society".

\section{2) Landasan Teoritis Corporate Social Respon- sibility}

\section{a. Teori Stakeholder (Stakeholder Theory)}

Hal pertama mengenai teori stakeholder adalah bahwa stakeholder adalah sistem yang secara eksplisit berbasis pada pandangan tentang suatu organisasi dan lingkungannya, mengakui sifat saling mempengaruhi antara keduanya yang kompleks dan dinamis.Stakeholder dan organisasi saling mempengaruhi, hal ini dapat dilihat dari hubungan sosial keduanya yang berbentuk responsibilitas dan akuntabilitas.Oleh karena itu organisasi memiliki akuntabilitas terhadap stakeholdernya.

Varian kedua teori stakeholder berhubungan dengan pandangan Trekers (1983) dalam Achmad (2007) mengenai emprical accountability. Robert
(1992) menyatakan bahwa pengungkapansosial perusahaan merupakan sarana yang sukses bagi perusahaan untuk menegosiasikan hubungan dengan stakeholdernya.

\section{b. Teori Legimitasi (Legitimacy Theory)}

Lindblom (1994) dalam Achmad (2007) menyatakan bahwa suatu organisasi mungkin menerapkan empat strategi legitimasi ketika menghadapi berbagai ancaman legitimasi. Oleh karena itu, untuk menghadapi kegagalan kinerja perusahaan (seperti kecelakaan yang serius atau skandal keuangan organisasi mungkin:

1) Mencoba untuk mendidik stakeholdernya tentang tujuan organisasi untuk meningkatkan kinerjanya.

2) Mencoba untuk merubah persepsi stakeholder terhadap suatu kejadian (tetapi tidak merubah kinerja aktual organisasi).

3) Mengalihkan (memanipulasi) perhatian dari masalah yang menjadi perhatian (mengkonsentrasikan terhadap beberapa aktivitas positif yang tidak berhubungan dengan kegagalan - kegagalan).

4) Mencoba untuk merubah ekspektasi eksternal tentang kinerjanya.

Teori legitimasi dalam bentuk umum memberikan pandangan yang penting terhadap praktek pengungkapan sosial perusahaan.Kebanyakan inisiatif utama pengungkapan sosial perusahaan bisa ditelusuri pada satu atau lebih strategi legitimasi yang disarankan oleh Lindblom.Sebagai missal, kecenderungan umum bagi pengungkapan sosial perusahaan untuk menekankan pada poin positif bagi perilaku organisasi dibandingkan dengan elemen yang negatif.

\section{c. Teori Kontrak Sosial (Social Contract Theo- ry)}

Teori ini muncul karena adanya interelasi dalam kehidupan sosial masyarakat, agar terjadi keselarasan, keserasian, dan keseimbangan, termasuk dalam lingkungan.Untuk itu, agar terjadi keseimbangan (equality), maka perlu kontrak sosial baik secara tersusun baik secara tersurat maupun tersirat, sehingga terjadi kesepakatan-kesepakatan yang saling melindungi kepentingan masingmasing (Nor Hadi.2011:96).

Social Contract dibangun dan dikembangkan, salah satunya untuk menjelaskan hubungan antara perusahaan terhadap masyarakat (society).Di sini, perusahaan atau organisasi memiliki kewajiban pada masyarakat untuk memberi manfaat bagi masyarakat. Interaksi perusahaan dengan masyarakat akan selalu berusaha untuk memenuhi dan mematuhi 
aturan dan norma-norma yang berlaku di masyarakat, sehingga kegiatan perusahaan dapat dipandang legitimate (Deegan, dalam Nor Hadi 2011:96).

\section{3) Pelaporan Program Corporate Social Re- sponsibility}

Laporan tanggungjawab sosial merupakan laporan aktivitas tanggungjawab sosial yang telah dilakukan perusahaan baik berkaitan dengan perhatian masalah dampak sosial maupun lingkungan. Laporan tersebut menjadi bagian yang tak terpisahkan dengan laporan tahunan (annual report) yang dipertanggungjawabkan direksi di depan sidang Rapat Umum Pemegang Saham (RUPS). Laporan ini berisi laporan program-program sosial dan lingkungan perseroan yang dilaksanakan selama tahun buku berakhir (Nor Hadi. 2011:206).

\section{4) Faktor-faktor yang Mempengaruhi Pengungkapan Corporate Social Responsibil- ity.}

\section{a. Profitabilitas.}

Dalam keterkaitan profitabilitas Amran dan Devi (2008) dalam Eka (2011) menyatakan bahwa suatu perusahaan yang memilki profit besar harus aktif melakukan CSR. Dengan profitabilitas yang tinggi, akan memberikan kesempatan yang lebih kepada manajemen dalam mengungkapkan serta melakukan program CSR. Oleh karena itu, semakin tinggi tingkat profitabilitas perusahaan maka akan semakin besar pengungkapan informasi sosial, Zaleha (2005) dalam Aulia (2010). Hasil penelitian yang dilakukan oleh Theodora (2011) juga menunjukkan bahwa profitabilitas berpengaruh terhadap pengungkapan CSR.

Penelitian ini akan menguji kembali pengaruh profitabilitas terhadap pengungkapan CSR dengan hipotesis sebagai berikut :

\section{H1 : Profitabilitas berpengaruh positif terhadap pengungkapan CSR.}

\section{b. Ukuran perusahaan.}

Hubungan antara ukuran perusahaan dengan pengungkapan sosial perusahaan telah ditunjukkan dalam beberapa penelitian empiris dalam Achmad 2007 (sebagai misal, Belkaoui dan Karpik, 1989; Cowen et. al., 1987; Kelly, 1981; Ng, 1981; Patten 1991, 1992; Trotman dan Bradley, 1981). Teori legitimasi memiliki alasan tentang hubungan ukuran dan pengungkapan.Perusahaan yang lebih besar melakukan aktivitas yang lebih banyak sehingga memiliki pengaruh yang lebih besar terhadap masyarakat, memilik lebih banyak pemegang sa- ham yang punya perhatian terhadap program sosial yang dilakukan perusahaan dan laporan tahunan merupakan alat yang efisien untuk mengkomunikasikan informasi ini (Cowen et Al., 1987) dalam Achmad (2007).

Oleh karena itu, konsisten dengan pendapat Cowen et Al.,maka hipotesis berikut dikemukakan :

\section{H2 : Ukuran perusahaan berpengaruh positif terhadap pengungkapan CSR.}

\section{c. Kepemilikan Saham Publik.}

Perusahaan go public dan telah terdaftar dalam BEI adalah perusahaan-perusahaan yang memiliki proporsi kepemilikan saham oleh publik, yang artinya bahwa semua aktivitas dan keadaan perusahaan harus dilaporkan dan diketahui oleh publik sebagai salah satu bagian pemegang saham. Akan tetapi tingkat kepemilikan sahamnya berbeda-beda satu sama lain. Penelitian oleh Hasibuan (2001) dalam Eka (2011) menjelaskan bahwa semakin tinggi rasio/tingkat kepemilikan publik dalam perusahaan diprediksi akan melakukan tingkat pengungkapan yang lebih luas.

Oleh karena itu, sejalan dengan pendapat oleh Hasibuan maka hipotesis berikut dikemukakan :

\section{H3 :Kepemilikan saham publik berpengaruh positif terhadap pengungkapan CSR.}

\section{d. Dewan Komisaris}

Dewan komisaris merupakan wakil shareholder dalam entitas bisnis yang berbadan hukum Perseroan Terbatas (PT) yang berfungsi mengawasi pengelolaan perusahaan yang dilaksanakan oleh manajemen (direksi), dan bertanggung-jawab untuk menentukan apakah manajemen memenuhi tanggung jawab mereka dalam mengembangkan dan menyelenggarakan pengendalian intern perusahaan (Mulyadi, 2002) dalam Ardilla (2011).Dengan wewenang yang dimiliki, dewan komisaris dapat memberikan pengaruh yang cukup kuat untuk menekan manajemen agar mengungkapkan informasi CSR lebih banyak, sehingga dapat dijelaskan bahwa perusahaan yang memiliki ukuran dewan komisaris yang lebih besar akan lebih banyak mengungkapkan CSR. Sebagai wakil dari prinsipal di dalam perusahaan, dewan komisaris dapat mempengaruhi luasnya pengungkapan tanggung jawab sosial, karena dewan komisaris merupakan pelaksana tertinggi didalam entitas. Dengan mengungkapkan tanggung jawab sosial perusahaan, maka image perusahaan akan semakin baik (Gray et al., 1988 dalam Fr.Reni, 2006). 
Konsisten dengan pendapat yang dikemukakan oleh Gray et al.,maka hipotesis berikut dikemukakan :

\section{H4 :Dewan Komisaris berpengaruh positif ter- hadap pengungkapan CSR.}

\section{e. Leverage}

Menurut Belkaoui dan Karpik (1989) dalam Eddy (2005) keputusan untuk mengungkapkan informasi sosial akan mengikuti suatu pengeluaran untuk pengungkapan yang menurunkan pendapatan. Sesuai dengan teori agensi maka manajemen perusahaan dengan tingkat leverage yang tinggi akan mengurangi pengungkapan tanggung jawab sosial yang dibuatnya agar tidak menjadi sorotan dari para debtholders. Hasil penelitian yang dilakukan oleh Aulia (2011) dan Lidya (2011) juga menunjukkan bahwa leverage berpengaruh negatif terhadap pengungkapan CSR.

Konsisten dengan penelitian yang dilakukan oleh Aulia (2011) dan Lidya (2011), variabel leverageakan diuji kembali pengaruhnya terhadap pengungkapan CSR. Oleh karena itu, hipotesis berikut dikemukakan :

\section{H5 :Leverage berpengaruh negatif terhadap pengungkapan CSR.}

\section{f. Pengungkapan Media.}

Jika perusahaan ingin mendapat kepercayaan dan legitimasimelalui kegiatan CSR, maka perusahaan harus mempunyai kapasitas untuk memenuhi kebutuhan pemangku kepentingan dan berkomunikasi dengan pemangku kepentingannya secara efektif.Fungsi komunikasi menjadi sangat pokok dalam manajemen CSR.Pengkomunikasian CSR melalui media akan meningkatkan reputasi perusahaan di mata masyarakat. Pada pelaksanaannya, hal inilah yang menjadi bagian pada proses membangun institusi, membentuk norma yang diterima dan legitimasi praktik CSR. Penelitian teori legitimasi secara luas menguji peran yang dimainkan oleh berita media pada peningkatan tekanan yang diakibatkan oleh tuntutan publik terhadap perusahaan.Media mempunyai peran penting pada pergerakan mobilisasi sosial, misalnya kelompok yang tertarik pada lingkungan (Patten, 2002b dalam Reverte, 2008).Menurut Simon (1992) dalam Reverte (2008), media adalah sumber daya pada informasi lingkungan.Hasil penelitian (Bansal and Clelland, 2004; Bansal and Roth, 2000; Bowen, 2000; Henriques and Sadorsky, 1996) dalam Reverte (2008) menunjukkan bahwa pengungkapan media berpengaruh positif terhadap pengungkapan CSR.
Oleh karena itu kosnsisten dengan hasil penelitian yang dilakukan oleh Bansal and Clelland, 2004; Bansal and Roth, 2000; Bowen, 2000; Henriques and Sadorsky, 1996 maka hipotesis berikut dikemukakan :

\section{H6 :Pengungkapan Media berpengaruh positif terhadap pengungkapan CSR.}

\section{B. Metode Penelitian}

\section{Populasi dan Sampel Penelitian}

Penelitian ini menggunakan populasi perusahaan berkategori high profile yang tercatat di Bursa Efek Indonesia tahun 2008-2010. Industri yang termasuk dalam perusahaan berkategori high profile adalah industri konstruksi, pertambangan, pertanian, kehutanan, perikanan, kimia, otomotif, barang konsumsi, makanan dan minuman, kertas, farmasi dan plastik (Fr. Reni,2006).

Penggunaan perusahaan high profile, karena perusahaan kategori tersebut memiliki visibilitas dari stakeholder, risiko politis yang tinggi, dan menghadapi persaingan yang tinggi. Industri high profile umumnya merupakan industri yang memperoleh sorotan dari masyarakat karena aktivitas operasinya memiliki potensi bersinggungan dengan kepentingan luas (stakeholder).Adapun pengambilan sampel dalam penelitian ini menggunakan purposive sampling.

\section{Definisi Operasional}

\section{1) Variabel Dependen}

Variabel dependen dalam penelitian adalah CSR Disclosure dengan menggunakan indikator dari Global Reporting Initiative (GRI) dengan jumlah 79 pengungkapan yang meliputi: economic (EC), environment (EN), human rights (HR), labor practices $(L P)$, product responsibility (PR) dan society $(S O)$.Kemudian check list dilakukan dengan melihat pengungkapan tanggung jawab sosial perusahaan dalam dimensi economic $(E C)$, environment (EN), human rights (HR), labor practices $(L P)$, product responsibility $(P R)$ dan society $(S O)$.

Kemudian dilakukan penghitungan indeks pengungkapan tanggung jawab sosial.

\section{$\mathrm{CSRDI}=$}

Jumlah item informasi CSR yang diungkapkan

2) Var79 item informasi CSR versi GRI 3.0 iabel Independen 
Variabel independen adalah tipe variabel yang menjelaskan atau mempengaruhi variabel yang lain. Variabel independen dalam penelitian ini meliputi:

\section{a. Profitabilitas}

Dalam penelitian ini, indikator yang digunakan adalah Return on Asset (ROA). Return on asset (ROA) merupakan ukuran efektifitas perusahaan di dalam menghasilkan keuntungan dengan memanfaatkan aktiva yang dimilikinya.

Adapun pengukurannya menggunakan rumus:

\section{Laba Bersih Setelah Pajak \\ b. Ukuran TotalAktiva Perus- ahaan}

Penelitian variabel ukuran perusahaan diukur dengan logaritma natural total asset. Ukuran perusahaan dirumuskan sebagai berikut:

$$
\text { SIZE }=\log \text { (nilai total aktiva). }
$$

\section{c. Kepemilikan Saham Publik}

Berdasarkan pengukuran yang telah dilakukan oleh Puspitasari (2009) dalam Eka (2011).

Rasio Kepemilikan saham publik:

Jumlah Kepemilikan Lembar Saham Publik

Total Lembar Saham Perusahaan $\% \times 100$

\section{d. Dewan Komisaris}

Dewan Komisaris (DK) adalah banyaknya jumlah anggota dewan komisaris dalam suatu perusahaan. Pengukuran dengan menggunakan rumus sebagai berikut:

\section{DK $=\Sigma$ Dewan Komisaris Perusahaan.}

\section{e. Leverage}

Dalam penelitian ini, indikator yang digunakan untuk mengukur tingkat leverage adalah Debt To Equity Ratio (DER). Adapun pengkurannya menggunakan rumus :

D E $\mathbf{R}=\frac{\text { TotalKewajiban }}{\text { Ekuitas }}$

\section{f. Pengungkapan Media}

Sebagimana penelitian yang dilakukan oleh Aulia (2010) dalam penelitian ini untuk mengukur pengungkapan media juga dilakukan dengan variabel dummy, yaitu dengan memberikan nilai 1 untuk perusahaan yang mengungkapkan kegiatan CSR di website perusahaan dan 0 untuk perusahaan yang tidak mengungkapkan kegiatan CSR di website perusahaan.

\section{Teknik pengumpulan data}

Metode pengumpulan data yang digunakan di dalam penelitian ini adalah metode studi dokumentasi dengan mendapatkan data berupa laporan tahunan dan laporan keberlanjutan yang telah dikeluarkan oleh perusahaan pada periode tahun 2008-2010. Data tersebut diperoleh melalui situs yang dimiliki oleh BEI, yakni www.idx.co.iddan websiteperusahaan.

\section{Teknik Analisis Data}

\section{Analisis Deskriptif}

Analisis Deskriptif dimaksudkan untuk memberikan gambaran atau deskripsi atas suatu data yang dilihat dari nilai rata-rata (mean), standar deviasi, varian, maksimum, minimum, sum.

\section{Pengujian Asumsi Klasik}

Pengujian regresi berganda dapat dilakukan setelah model dari penelitian ini memenuhi syarat-syarat lolos dari asumsi klasik.Syarat-syarat tersebut harus terdistribusi secara normal, tidak mengandung multikolinearitas, autokorelasi, dan heteroskedastisitas.

\section{a. Uji Normalitas}

Uji normalitas yang dilakukan dalam penelitian ini dengan uji Kolmogorov untuk memutuskan apakah sebuah sampel dapat berasal dari sebuah distribusi normal (Sprent, 1991). Karena hasilnya berupa angka, bukan gambar, maka lebih mudah untuk memutuskan residual berdistribusi normal atau tidak.

\section{b. Uji Multikolinearitas}

Dalam penelitian ini, multikolinearitas juga dapat dilihat dari a) nilai tolerance dan lawannya b) variance inflation factor (VIF).Kedua ukuran ini menunjukkan setiap variabel independen manakah yang dijelaskan oleh variabel independen lainnya.Tolerance mengukur variabilitas variabel independen yang terpilih yang tidak dijelaskan oleh variabel independen lainnya. Jadi nilai tolerance yang tinggi sama dengan nilai VIF tinggi (karena $\mathrm{VIF}=1 /$ Tolerance). Nilai cutoff yang umum dipakai untuk menunjukkan adanya multikolinearitas adalah nilai Tolerance $<0.10$ atau sama dengan nilai VIF $>10$ dengan tingkat kolonieritas 0.50 . 


\section{c. Uji Autokorelasi}

Dalam penelitian uji autokorelasi dilakukan dengan menggunakan uji Durbin Watson ini, dengan uji ini akan didapatkan nilai DW. Nilai ini akan dibandingkan dengan nilai tabel dengan menggunakan nilai signifikansi 5\%, jumlah sampel (n) dan jumlah variabel. Suatu model dapat dikatakan bebas dari autokolerasi positif ataupun autokolerasi negatif apabila nilai DW tersebut lebih besar dari batas atas $(d u)$ dan kurang dari 4- $d u$.

Uji Durbin Watson hanya digunakan untuk autokolerasi tingkat satu (first order autocorrelation) dan mensyaratkan adanya intercept (konstanta) dalam model regresi dan tidak ada variabel lag diantara variabel independen (Ghozali, 2011).

\section{d. Uji Heteroskedastisitas}

Dalam penelitian ini uji heteroskedastisitas dilakukan dengan model metode Park adalah $\operatorname{Ln}\left(\mathrm{e}^{2}\right)$ $=a+\beta \operatorname{LnX}_{\mathrm{i}}$. Jika secara statistik signifikan, maka hal ini menunjukkan kehadiran situasi heteroskedastisitas (Arief, 1992).

\section{Pengujian Hipotesis}

\section{Analisis regresi}

Pengujian ini menggunakan regresi berganda untuk menghubungkan satu variabel dependen dengan beberapa variabel independen. Uji hipotesis dalam penelitian ini meliputi:

\section{1). Model Regresi Berganda.}

Dalam penelitian ini Analisis Regresi Berganda digunakan untuk mengetahui ada tidaknya pengaruh profitabiltas, ukuran perusahaan, kepemilikan saham pulik, ukuran dewan komisaris, leverage dan pengungkapan media, perusahaan terhadap indeks praktik pengungkapan CSR suatu perusahaan. Model persamaan regresi dalam penelitian ini adalah sebagai berikut:

$$
\begin{aligned}
\mathrm{Y}= & \mathrm{a}+\mathrm{b} 1 \mathrm{X} 1+\mathrm{b} 2 \mathrm{X} 2+\mathrm{b} 3 \mathrm{X} 3+\mathrm{b} 4 \mathrm{X} 4+\mathrm{b} 5 \mathrm{X} 5+ \\
& \mathrm{b} 6 \mathrm{X} 6+\mathrm{e}
\end{aligned}
$$

Dimana:

$\mathrm{Y}=$ Indeks pengungkapan CSR suatu perusahaan.

$\mathrm{a}=$ Konstanta.

\section{Hasil Penelitian dan Pembahasan}

Tabel Statistik Deskriptif.

\begin{tabular}{|c|c|c|c|c|}
\hline & & CSRDI & Profitabilitas & Ukuran Perusahaan \\
\hline \multirow[t]{2}{*}{$\mathrm{N}$} & Valid & 66 & 66 & 66 \\
\hline & Missing & 0 & 0 & 0 \\
\hline \multicolumn{2}{|c|}{ Mean } & .2808 & .1327 & 17330757683155.120 \\
\hline \multicolumn{2}{|c|}{ Median } & .2050 & .1225 & 6889848500000.000 \\
\hline \multicolumn{2}{|c|}{ Mode } & $.14^{a}$ & $.03^{a}$ & $1111100000000.000^{a}$ \\
\hline \multicolumn{2}{|c|}{ Std. Deviation } & 19962 & .10832 & 24111185099325.770 \\
\hline \multicolumn{2}{|c|}{ Variance } & .040 & .012 & 581349246893949000000000000.000 \\
\hline \multicolumn{2}{|c|}{ Minimum } & .10 & .00 & 1111100000000.000 \\
\hline \multicolumn{2}{|c|}{ Maximum } & 1.00 & .56 & 112857000000000.000 \\
\hline \multicolumn{2}{|c|}{ Sum } & 18.53 & 8.76 & 1143830007088238.000 \\
\hline
\end{tabular}

Statistics

a. Multiple modes exist. The smallest value is shown

\begin{tabular}{|c|c|c|c|c|c|}
\hline & & $\begin{array}{c}\text { Kepemilikan } \\
\text { saham publik } \\
(\%)\end{array}$ & $\begin{array}{l}\text { Ukuran } \\
\text { Dewan } \\
\text { Komisaris }\end{array}$ & Leverage & $\begin{array}{l}\text { Pengungkapan } \\
\text { Media }\end{array}$ \\
\hline \multirow[t]{2}{*}{$\overline{\mathrm{N}}$} & Valid & 66 & 66 & 66 & 66 \\
\hline & Missing & 0 & 0 & 0 & 0 \\
\hline \multicolumn{2}{|c|}{ Mean } & 31.6830 & 6.1970 & 1.1283 & .9091 \\
\hline \multicolumn{2}{|c|}{ Median } & 28.1500 & 5.0000 & 1.0000 & 1.0000 \\
\hline \multicolumn{2}{|c|}{ Mode } & $15.00^{a}$ & 5.00 & $.60^{a}$ & 1.00 \\
\hline \multicolumn{2}{|c|}{ Std. Deviation } & 18.72884 & 2.07713 & .88603 & .28968 \\
\hline \multicolumn{2}{|c|}{ Variance } & 350.770 & 4.314 & .785 & .084 \\
\hline \multicolumn{2}{|c|}{ Minimum } & 4.35 & 3.00 & .18 & .00 \\
\hline \multicolumn{2}{|c|}{ Maximum } & 82.13 & 11.00 & 4.05 & 1.00 \\
\hline \multicolumn{2}{|c|}{ Sum } & 2091.08 & 409.00 & 74.47 & 60.00 \\
\hline
\end{tabular}

Statistics

a. Multiple modes exist. The smallest value is shown 
$\mathrm{b}=$ Koefisien regresi model.

$\mathrm{X} 1$ :Profitabilitas.

$\mathrm{X} 2$ :Ukuran Perusahaan.

X3 : Kepemilikan Saham Publik.

X4 : Dewan Komisaris.

$\mathrm{X} 5$ :Leverage.

X6 : Pengungkapan Media.

$\mathrm{e}=$ error term model (variabel residual).

Berdasarkan hasil tabel statistik deskrif di atas terdapat 7 variabel yaitu variabel Corporate Social Responsibility, profitabilitas, ukuran perusahaan, kepemilikan saham publik, dewan komisaris, leverage dan pengungkapan media.Pada variabel CSR menunjukkan bahwa pengungkapan rasio terkecil (minimum) adalah 0,10 dan rasio terbesar (maximum) adalah 1. Rata-rata pengungkapan CSR dari 66 perusahaan adalah 0,2808.

Hasil tabel statistik deskrif variabel profitabilitas menunjukkan bahwa nilai minimum adalah 0,003 dan nilai maximum adalah 0,56 dengan rata-rata profitabilitas adalah 0,1327 . Variabel ukuran perusahaan menunjukkan nilai minimum 1.111.100.000.000 dengan nilai maksimum adalah 112.857.000.000.000dan dengan nilai rata-rata 17.330.757.683.155,12.

Hasil tabel statistik deskrif variabel kepemilikan saham publiknilai minimum dari kepemilikan saham publikadalah 4,35 \%dengan nilai maksimum adalah 82,13 \% dengan nilai rata-rata 31,68\%. Adapun Variabel ukuran perusahaan menunjukkan nilai nilai minimum dari dewan komisarisadalah 3dengan nilai maksimum adalah 11 dan dengan nilai rata-rata 6,197 .

Hasil tabel statistik deskrif variabel kepemilikan saham publiknilai minimum dari leverageadalah

\section{Uji Normalitas}

One-Sample Kolmogorov-Smirnov Test

\begin{tabular}{|ll|r|}
\hline & & \multicolumn{1}{|c|}{$\begin{array}{c}\text { Standardized } \\
\text { Residual }\end{array}$} \\
\hline N & & 66 \\
Normal Parameters a,b & Mean & .0000000 \\
Most Extreme & Std. Deviation & .95272887 \\
Differences & Absolute & .087 \\
& Positive & .087 \\
Kolmogorov-Smirnov Z & Negative & -.068 \\
Asymp. Sig. (2-tailed) & & .711 \\
\hline
\end{tabular}

a. Test distribution is Normal.

b. Calculated from data.

Berdasarkan gambar grafik plot dapat diketahui bahwa titik-titik menyebar di sekitar garis diagonal dan penyebarannya mengikuti arah garis diagonal. Dengan demikian dapat dinyatakan bahwa penyebaran data memenuhi normalitas.Berdasarkan hasil uji dengan Kolmogorov Smirnov bahwa data terdistribusi normal. Hal ini dapat dilihat dari Asymp. Sig (2-tailed) Sig $(=0,693)>a(=0,05)$ berarti normal.

\section{Uji Multikolinearitas}

\section{Tabel 3. Hasil Uji Multikolinearitas}

\begin{tabular}{|l|l|l|}
\hline Variabel & VIF & Kesimpulan \\
\hline Profitabilitas & 1,722 & Tidak ada Multikolinearitas \\
\hline Ukuran Perusahaan & 3,456 & Tidak ada Multikolinearitas \\
\hline Kepemilikan saham publik & 1,751 & Tidak ada Multikolinearitas \\
\hline Dewan Komisaris & 2,215 & Tidak ada Multikolinearitas \\
\hline Leverage & 2,337 & Tidak ada Multikolinearitas \\
\hline Pengungkapan Media & 1,176 & Tidak ada Multikolinearitas \\
\hline
\end{tabular}

Dari tabel diatas terlihat bahwa semua nilai VIF dari hasil regresi parsial di bawah 10.Sehingga dapat disimpulkan bahwa tidak terjadi Multikolonearitas.

\section{Uji Autokorelasi}

Dari tabel Durbin Watson dengan tingkat nilai signifikansi 5\%, dengan n 66 di ketahui dL sebesar 1,404 dan dU sebesar 1,805. Adapun hasil perhi- 
tungan Durbin Watson sebesar 1,899. Nilai ini berada pada daerah $1,805<1,899<2$ sehingga dapat disimpulkan bahwa data tersebut.

\section{Uji Heteroskedasititas}

Berikut ini adalah hasil rangkuman Heteroskedastisitas dengan menggunakan Uji Park.

Tabel Hasil Uji Heteroskedastisitas

\begin{tabular}{|l|l|l|l|}
\hline Variabel & T-Hitung & Sig & Kesimpulan \\
\hline Profitabilitas & $-0,819$ & 0,416 & $\begin{array}{l}\text { Tidak ada Heteroske- } \\
\text { dastisitas }\end{array}$ \\
\hline Ukuran Perusahaan & 0,899 & 0,372 & $\begin{array}{l}\text { Tidak ada Heteroske- } \\
\text { dastisitas }\end{array}$ \\
\hline Kepemilikan Saham Publik & 1,758 & 0,84 & $\begin{array}{l}\text { Tidak ada Heteroske- } \\
\text { dastisitas }\end{array}$ \\
\hline Dewan Komisaris & $-1,300$ & 0,199 & $\begin{array}{l}\text { Tidak ada Heteroske- } \\
\text { dastisitas }\end{array}$ \\
\hline Leverage & $-1,374$ & 0,175 & $\begin{array}{l}\text { Tidak ada Heteroske- } \\
\text { dastisitas }\end{array}$ \\
\hline Pengungkapan Media & 0,445 & 0,658 & $\begin{array}{l}\text { Tidak ada Heteroske- } \\
\text { dastisitas }\end{array}$ \\
\hline
\end{tabular}

Dari hasil perhitungan tersebut ternyata dalam model regresi tersebut semua menunjukkan thitung $<\mathrm{t}$-tabel atau signifikansi $>0,05$, sehingga dapat disimpulkan bahwa dalam model regresi ini tidak terjadi heteroskedastisitas.

Pengujian Regresi Berganda

Analisis regresi berganda bertujuan untuk menge- tahui pengaruh variabel-variabel independen yaitu profitabilitas, ukuran perusahaan, kepemilikan saham publik, ukuran dewan komisaris, leverage dan pengungkapan media terhadap pengungkapan Corporate Social Responsibility pada perusahaan berkategori high profile yang listing di Bursa Efek Indonesia periode 2008-2010. Berikut ini adalah rangkuman hasil regresi berganda :

\section{Tabel Hasil Analisis Regresi Berganda}

\begin{tabular}{|c|c|c|c|c|}
\hline Variabel & $\begin{array}{l}\text { Koef. Re- } \\
\text { gresi }\end{array}$ & t.hitung & Sig & Keterangan \\
\hline Konstanta & $-12,185$ & $-5,703$ & 0,000 & Signifikan \\
\hline Profitabilitas & $-0,028$ & $-0,378$ & 0,707 & Tidak Signifikan \\
\hline Ukuran Perusahaan & 0,418 & 4,773 & 0,000 & Signifikan \\
\hline $\begin{array}{ll}\text { Kepemilikan } & \text { Sa- } \\
\text { ham Publik }\end{array}$ & $-0,092$ & $-0,818$ & 0,417 & Tidak Signifikan \\
\hline Dewan Komisaris & $-0,792$ & $-3,057$ & 0,003 & Signifikan \\
\hline Leverage & $-0,331$ & $-3,143$ & 0,003 & Signifikan \\
\hline $\begin{array}{l}\text { Pengungkapan Me- } \\
\text { dia }\end{array}$ & $-0,143$ & $-0,689$ & 0,494 & Tidak Signifikan \\
\hline $\begin{array}{l}\text { R 0,592 } \\
\text { R Square } 0,350 \\
\text { N } 66 \\
\end{array}$ & & \multicolumn{3}{|c|}{$\begin{array}{l}\text { F hitung } 5,925 \\
\text { Sig } 0,000\end{array}$} \\
\hline
\end{tabular}

Berdasarkan hasil perhitungan regresi secara keseluruhan, diperoleh hasil persamaan regresi sebagai berikut :
CSR $=-12,185-0,028$ Profitabilitas $+0,418$

Ukuran Perusahaan -0,092 Kepemilikan Publik

- 0,792 Dewan Komisaris - 0,331 Leverage 0,143 Pengungkapan Media. 


\section{Pembahasan}

1. Hasil penelitian menunjukkan profitabilitas yang diproksi dengan ROA menunjukkan pengaruh yang tidak signifikan terhadap pengungkapan CSR dengan $\mathrm{t}$ hitung sebesar 0,378 pada tingkat signifikansi 0,707 atau probabilitas di atas $a=5 \%$. Ini berarti bahwa besar kecilnya profitabilitas tidak akan mempenga -ruhi tingkat pengungkapan tanggung jawab sosial perusahaan. Hasil ini mungkin sesuai dengan pendapat Kokubu et. al., (2001) dalam Edy (2005) yang menyatakan bahwa political visibility perusahaan tergantung pada ukuran (size), bukannya pada profitabilitasnya.

Hasil penelitian ini berbeda dengan hasil penelitian Theodora (2010) yang menyatakan bahwa profitabilitas memiliki pengaruh positif dan signifikan terhadap pengungkapan CSR. Akan tetapi hasil penelitian ini sesuai dengan hasil penelitian Aulia (2010), Fr Reni (2006) dan Edy (2005) yang menemukan profitabilitas tidak berpengaruh signifikan terhadap pengungkapan tanggung jawab sosial perusahaan.Hasil penelitian ini juga tidak berhasil mendukung teori legitimasiyang dinyatakan oleh Donovan dan Gibson (2000) dalam Achmad (2007) bahwa profitabilitasberpengaruh negatif terhadap pengungkapan tanggung jawab sosial perusahaan. Hal ini didukung dengan argumentasi bahwa ketika perusahaan memiliki tingkat laba yang tinggi, perusahaan (manajemen) menganggap tidak perlu melaporkan hal-hal yang dapat mengganggu informasi tentang sukses keuangan perusahaan. Sebaliknya, pada saat tingkat profitabilitas rendah, mereka berharap para pengguna laporan akan membaca "good news" kinerja sosial dan lingkungan yang dilakukan perusahaan.

2. Walaupun profitabilitas tidak berpengaruh signifikan terhadap pengungkapan CSR, ukuran perusahaan yang diukur dengan total asset berpengaruh positif dan signifikan terhadap pengungkapan CSR dengan nilai t hitung 4,773 dan siginikansi 0,000. Hal ini dapat diintrepretasikan bahwa semakin banyak jumlah aset maka akan semakin banyak pengungkapan CSR yang akan dilakukan perusahaan. Hasil penelitian ini mendukung penelitian yang dilakukan oleh Eddy (2005), Jayanti (2011) akan tetapi berbeda dengan hasil penelitian Fr. Reni (2006) dan Aulia (2011) yang menemukan bahwa ukuran perusahaan tidak berpengaruh signifikan terhadap pengungkapan CSR.

Hasil penelitian ini juga mendukung teori agen- si yang secara umum menyatakan bahwa semakin besar ukuran perusahaan maka pengungkapan CSR yang akan dilakukan akan semakin luas. Teori agensi yang menyatakan bahwa semakin besar suatu perusahaan maka biaya keagenan yang muncul juga semakin besar. Untuk mengurangi biaya keagenan tersebut, perusahaan akan cenderung mengungkapkan informasi yang lebih luas. Selain itu, perusahaan besar merupakan emiten yang banyak disoroti, pengungkapan yang lebih besar merupakan pengurangan biaya politis sebagai wujud tanggung jawab sosial perusahaan. Menurut Cowen et. al., (1987) dalam Eddy (2005), secara teoritis perusahaan besar tidak akan lepas dari tekanan, dan perusahaan yang lebih besar dengan aktivitas operasi dan pengaruh yang lebih besar terhadap masyarakat mungkin akan memiliki pemegang saham yang memperhatikan program sosial yang dibuat perusahaan sehingga pengungkapan tanggung jawab sosial perusahaan akan semakin luas.

3. Hasil penelitian menunjukkan bahwa kepemilikan saham publik tidak berpengaruh terhadap pengungkapan Corporate Social Responsibility dengan koefisien regresi -0,092 dengan t hitung $-0,818$ dan tingkat signifikansi 0,417. Hasil penelitian ini sejalan dengan penelitian yang dilakukan oleh Achmad Badjuri (2011), Eka (2011), Rivi dan Hasan (2011) bahwa kepemilikan saham publik tidak berpengaruh terhadap pengungkapan CSR.

Hal ini berarti bahwa tinggi rendahnya kepemilikan saham publik tidak mempengaruhi pengungkapan Corporate Social Responsibility. Hasil penelitian ini juga bertentangan dengan teori Hasibuan (2001) dalam Rivi dan Hasan (2011) yang menyatakan bahwa rasio kepemilikan publik yang tinggi diprediksikan perushaan akan melakukan tingkat pengungkapan sosial yang lebih, hal ini dikaitkan dengan tekanan dari pemegang saham, agar perusahaan lebih memperhatikan tanggung jawabnya terhadap masyarakat.

Alasan yang dapat digunakan untuk menjelaskan penelitian ini adalah bahwa kemungkinan kepemilikan publik pada perusahaan di Indonesia secara umum belum memperdulikan masalah lingkungan dan sosial sebagai isu kritis yang harus secara ekstensif untuk diungkapkan dalam laporan tahunan Rahma dan Indah (2010).

4. Hasilpenelitian menunjukkan bahwa dewan komisarisberpengaruh signifikan dan negatif 
terhadap pengungkapan CSR dengan $t$ hitung sebesar -3,057 pada tingkat signifikansi 0,003 atau di bawah $a=5 \%$. Hasil penelitian ini sesuai dengan penelitian yang dilakukan Luqman (2010) dan Chandra (2011) bahwa dewan komisaris berpengaruh negatif terhadap pengungkapan CSR. Akan tetapi, hasil penelitian ini berbeda dengan hasil penelitian yang dilakukan oleh Theodora dan Agus (2010) dan Eddy (2005) yang menyatakan bahwa dewan komisaris berpengaruh positif dan signifikan terhadap pengungkapan CSR.

Hal ini berarti apabila dewan komisaris berjumlah kecil maka perusahaan akan melakukan pengungkapan Corporate Social Responsibility yang lebih baik dibandingkan dengan dewan komisaris yang berjumlah besar. Alasan yang bisa menjelaskan ini dikarenakan dewan komisaris yang berjumlah kecil akan memiliki efektivitas yang baik terhadap pengawasan manajemen perusahaan. Selain itu, dewan komisaris yang berjumlah besar juga menjadi kurang efektif karena dominasi anggota dewan komisaris yang mementingkan kepentingan pribadi atau kepentingan kelompoknya sehingga mengesampingkan kepentingan perusahaan (Muntoro,2006) dalam Waryanto (2010). Oleh karena itu, seharusnya pembentukan dewan komisaris harus memperhatikan komposisi, kemampuan, dan integritas anggota sehingga dapat melakukan fungsi pengawasan, pengendalian dan memberikan arahan yang baik demi kepentingan perusahaan (Waryanto, 2010).

5. Hipotesis kelima yaitu, terdapat pengaruh negatif leverage terhadap pengungkapan Corporate Social Responsibility. Dalam penelitian ini leverage yang diproksi dengan DER (Debt Equity Ratio) menunjukkan pengaruh yang signifikan dan negatif terhadap pengungkapan CSR dengan t-hitung -3,143 pada tingkat signifikansi 0,003 atau leverage di bawah $a=5 \%$. Hasil penelitian ini sesuai dengan penelitian yang dilakukan oleh Lidya (2011) dan Aulia (2011) tetapi berbeda dengan hasil penelitian Fr. Reni (2006) dan Eddy (2005) yang menemukan bahwa leverage tidak memiliki pengaruh terhadap pengungkapan Corporate Social Responsibility.

Akan tetapi penelitian inimendukung teori agensi, yang menyatakan bahwa, tingkat leverage mempunyai pengaruh negatif terhadap pengungkapan tanggung jawab sosial. Manajemen perusahaan dengan tingkat leverage yang tinggi cenderung mengurangi pengungkapan tanggung jawab sosial yang dibuatnya agar tidak menjadi sorotan dari para debtholders (Eddy,2005).

6. Hasil penelitian menunjukkanpengungkapan media tidak berpengaruh terhadap pengungkapan CSR dengan nilai t hitung sebesar $-0,689$ dan diperoleh nilai signifikansi sebesar 0,494. Hasil penelitian ini sesuai dengan penelitian yang dilakukan oleh Aulia (2011) yang menemukan bahwa pengungkapan media tidak memiliki pengaruh signifikan terhadap pengungkapan Corporate Social Responsibility.

Alasan yang dapat menjelaskan hal ini dikarenakan website perusahaan telah digunakan sebagai sarana komunikasi pelaporan keuangan, walaupun keberadaan pelaporan keuangan dalam website yang dibuat oleh perusahaan belum terdapat kuantitas dan kualitas yang terstandarisasi antar perusahaan (Luciana,2009). Selain itu, mengingat pesatnya penggunaan internet di kalangan masyarakat, pemanfaatan website perusahaan untuk mengomunikasikan program CSR juga telah dipertimbangkan(Ati ,2011).

Hasil penelitian ini juga bertentangan dengan teori yang menyatakan bahwa pengkomunikasian CSR melalui media yang menjadi bagian proses membangun institusi, membentuk norma yang diterima dan legitimasi praktik CSR (Reverte,2008). Akan tetapi, media lebih berperan sebagai sarana perusahaan bukan sebagai exposure media yang mendorong perusahaan melakukan pengungkapan CSR karena perusahaan yang ingin mendapat kepercayaan danlegitimasi melalui kegiatan CSR, maka perusahaan harusmempunyai kapasitas untuk memenuhi kebutuhan pemangkukepentingan dan berkomunikasi dengan pemangku kepentingannya secara efektif (Ati,2011).

\section{Penutup \\ 1. Kesimpulan}

Berdasarkan hasil penelitian dan pembahasan, maka dapat ditarik kesimpulan sebagai berikut:

Profitabilitasyang diproksi dengan ROA tidak berpengaruh terhadap pengungkapan CSR hal ini dikarenakan ketika perusahaan memiliki tingkat laba yang tinggi, perusahaan (manajemen) menganggap tidak perlu melaporkan hal-hal yang dapat mengganggu informasi tentang sukses keuangan perusahaan.

Ukuran perusahaan yang diukur dengan Total Assetberpengaruh positif dan signifikan terhadap 
pengungkapan CSR hal ini dikarenakan semakin besar suatu perusahaan maka biaya keagenan yang muncul juga semakin besar. Untuk mengurangi biaya keagenan tersebut, perusahaan akan cenderung mengungkapkan informasi yang lebih luas.

Kepemilikan saham publik tidak berpengaruh terhadap pengungkapan CSR hal ini dikarenakan kemungkinan kepemilikan publik pada perusahaan di Indonesia secara umum belum mempedulikan masalah lingkungan dan sosial sebagai isu kritis yang harus secara ekstensif untuk diungkapkan dalam laporan tahunan.

Dewan komisarismenunjukkan pengaruh yang signifikan dan negatif terhadap pengungkapan CSR alasan yang bisa menjelaskan ini dikarenakan dewan komisaris yang berjumlah kecil akan memiliki efektivitas yang baik terhadap pengawasan manajemen perusahaan. Selain itu, ukuran dewan komisaris yang berjumlah besar juga menjadi kurang efektif karena dominasi anggota dewan komisaris yang mementingkan kepentingan pribadi atau kepentingan kelompoknya sehingga mengesampingkan kepentingan perusahaan.

Leverage yang diproksi dengan DER (Debt Equity Ratio)menunjukkan pengaruh yang signifikan dan negatif terhadap pengungkapan CSR hal ini dikarenakan manajemen perusahaan dengan tingkat leverage yang tinggi cenderung mengurangi pengungkapan tanggung jawab sosial yang dibuatnya agar tidak menjadi sorotan dari para debtholders.

Pengungkapan media tidak berpengaruh terhadap pengungkapan CSR hal ini dikarenakan media lebih berperan sebagai sarana perusahaan bukan sebagai exposure media yang mendorong perusahaan melakukan pengungkapan CSR

Profitabiltas, ukuran perusahaan, kepemilikan saham publik, dewan komisaris, leverage dan pengungkapan media secara bersama-sama mempengaruhi pengungkapan CSR

\section{Keterbatasan penelitian}

Terdapat beberapa keterbatasan dalam penelitian ini, keterbatasan tersebut antara lain :

1. Terdapat unsur subyektivitas pada penilaian indeks CSR.

2. Penilaian pengungkapan media hanya menggunakan website perusahaan.

3. Terdapat berbagai kriteria dalam penentuan perusahaan berkategori high profile, sehingga terdapat berbagai macam klasifikasi high profile menurut berbagai peneliti.

\section{Saran}

Berdasarkan hasil penelitian serta hal-hal yang terkait dengan keterbatasan penelitian, maka terdapat beberapa hal yang perlu diperhatikan yaitu :

1. Bagi investor dan calon investor perusahaan berkategori high profile yang terdaftar di Bursa Efek Indonesia agar lebih seksama dan juga memperhatikan aspek Corporate Social Responsibility perusahaan sebagai pertimbangan dalam melakukan investasi.

2. Bagi peneliti selanjutnya :

a. Pada penelitian selanjutnya dapat menggunakan sustainabilityreporting yang telah dikroscek oleh Global Reporting Initiative, ini untuk menghindari penilaian secara subjektif.

b. Penelitian selanjutnya apabila akan menggunakan variabel pengungkapan media, sebaiknya tidak hanya mengandalkan pada websiteperusahaan tetapi juga dapat memanfaatkan majalah bisnis, koran maupun media televisi.

c. Untuk memperoleh hasil penelitian yang lebih baik, penelitian selanjutnya dapat memperpanjang periode penelitian.

d. Populasi penelitian tidak hanya dikhususkan pada perusahaan berkategori high profile, tetapi dapat diperluas pada perusahaan yang terdaftar di Bursa Efek Indonesia.

\section{E. DAFTAR PUSTAKA}

Achmad Zaenuddin. (2007). Faktor-Faktor Yang Berpengaruh Terhadap Praktek Pengungkapan Sosial Dan Lingkungan Pada Perusahaan Manufaktur Go Publik. Tesis. Universitas Diponegoro.

Arif Rahman Dan Kurnia Widya Sari. (2008). The Analysis Of Company Characteristic Influence Toward Csr Disclosure : Empirical Evidence of Manufacturing Companies Listed In Jsx. Jaai Volume 12 No.1, Juni 2008 : 25-35

Ati Harmoni. (2010). Media Richness Theory Dan Potensi Website Sebagai Media Komunikasi Csr Oleh Perusahaan. Jurnal Ekonomi Bisnis, Nomor I Vol 15, 9-17. April 2010

Aulia Zahra Munif. (2010). Faktor-Faktor Yang Mempengaruhi Indeks Pengungkapan Corporate 


\section{Jurnal Nominal / Volume I Nomor I / Tahun 2012}

Social Responsibility Di Indonesia (Studi Empiris Pada Perusahaan Non Keuangan Yang Listing Di Bursa Efek Indonesia).Tesis. Universitas Diponegoro.

Chandra Kinanti. (2011). Pengaruh Perusahaan, Jumlah Ukuran Dewan Komisaris, Dan Kepemilikan Saham Publik Terhadap Pengungkapan Sosial Dalam Laporan Tahunan Sebagai Wujud Akuntabilitas Perusahaan. Skripsi UM

Eddy Rismanda Sembiring. (2005). Karakteristik Perusahaan Dan Pengungkapan Tanggung Jawab Sosial: Study Empiris Pada Perusahaan Yang Tercatat Di Bursa Efek Jakarta. Makalah SNA IV

Eka Nanda Putra. (2011). Pengaruh Karakteristik Perusahaan Terhadap Pengungkapan Corporate Social Responsibility (Csr). Skripsi Universitas Diponegoro

Fr. Reni. Retno Anggraini.(2006). Pengungkapan Informasi Sosial dan Faktor-Faktor yang Mempengaruhi Pengungkapan Informasi Sosial dalam Laporan Keuangan Tahunan (Studi Empiris pada Perusahaan-Perusahaan yang terdaftar Bursa Efek Jakarta. Makalah SNA IX

Ghozali, I. (2011). Aplikasi Analisis multivariate dengan Program IBM SPSS 19. Semarang : Badan Penerbit Fakultas Ekonomi Universitas Diponegoro

Global Reporting Initiative. GRI Sustainability Reporting GuideLines G3. (Webiste https:// www.globalreporting.org/.diakses pada 10 Januari 2012).

Hadi, Nor. (2011). Corporate Social Responsibility. Yogyakarta. Graha Ilmu

Ikatan Akuntansi Indonesia. (2009). Standar Akuntansi Keuangan, Paragraph 9, Salemba Empat, Jakarta.

Luqman Hakim. (2010). Pertimbangan Investor Berinvestasi Dan Faktor-Faktor Yang Mempengaruhi Pengungkapan Corporate Social Responsibility Perusahaan Go Publik Di Bursa Efek Indonesia. Disertasi. UM

Lidya Yulita. (2011). The Effect Characteristics Of Company Toward Corporate Social Responsibility Disclosures In Mining Company Listed At.. Jurnal Reformasi Ekonomi, Vol. 4, No. 1
Luciana Spica Almilia. (2008). Faktor-Faktor Yang Mempengaruhi Pengungkapan Sukarela Internet Financial And Sustainability Reporting. Jaai Volume 12 No. 2, Desember: 117 - 131.

Rahmawati dan Indah Dewi Utami.(2010). Pengaruh Ukuran Perusahaan, Ukuran Dewan Komisaris, Kepemilikan Institusional, Kepemilikan Asing, Dan Umur Perusahaan Terhadap Corporate Social Responsibility Disclosure Pada Perusahaan Property Dan Real Estate Yang Terdaftar Di Bursa Efek Indonesia. Jurnal Akuntansi Manajemen Vol 21 No 3 Desember 2010. STIE YKPN

Reverte, C. (2008). Determinants of Corporate Social Responsibility Disclosure Ratings by Spanish Listed Firms.Journal of Business Ethics (2009) 88:351-366 DOI 10.1007/s10551-008-9968-9

Rivi Hamdani W dan Hasan Sakti S. (2011). Pengaruh Sisi Internal Dan Sisi Eksternal Perusahaan Terhadap Pengungkapan Tanggung Jawab Sosial Perusahaan Pada Perusahaan Yang Terdaftar Di BEI. Jurnal Ekonomi Vol 14, No 4 September 2011. 180-190

Theodora Martina Veronica, Drs. Agus Sumin, Mm. (2010). The Effect Of Company Charactheristic On Disclosure Of Social Responsibility In Mining Corporate Sector Listed In Indonesia Stock Exchange. Jurnal Akuntansi Keuangan, Vol.12 No.1.2010.

Waryanto. (2010). Pengaruh Karakteristik Good Corporate Governance (GCG) Terhadap Luas Pengungkapan Corporate Social Responsibility Di Indonesia. Skripsi Universitas Diponegoro.

Yoga Nata Adikara. (2011). Pengaruh Karakteristik Perusahaan Terhadap Pengungkapan Tanggung Jawab Sosial Dalam Laporan Tahunan Perusahaan Yang Terdaftar Di Bursa Efek Indonesia. Skripsi Universitas Diponegoro. 